Pesq. Vet. Bras. 29(5):363-368, maio 2009

\title{
Analysis of Escherichia coli isolated from bovine mastitic milk ${ }^{1}$
}

\author{
Patricia Rangel ${ }^{2}$ and José Moacir Marin ${ }^{3 *}$
}

\begin{abstract}
Rangel P. \& Marin J.M. 2009. Analysis of Escherichia coli isolated from bovine mastitic milk. Pesquisa Veterinária Brasileira 29(5):363-368. Departamento de Morfologia, Estomatologia e Fisiologia, Faculdade de Odontologia de Ribeirão Preto, Universidade de São Paulo, Avenida do Café s/n, Campus USP, Ribeirão Preto, SP 14040-904, Brazil. E-mail: jmmarin@ forp.usp.br

Mastitis has been recognized for some time as the most costly disease in dairy herds. From February to November 2004, 670 samples of bovine mastitic milk from which 231 Escherichia colistrains were isolated, were collected from two Brazilian states. The strains were screened for the presence of Shiga toxin-producing (stx 1 and stx 2 ) and intimin (eae) genes. Twenty (8.6\%) strains were detected by PCR to harbor the Shiga toxin genes (8 the stx 1 gene, 12 the stx 2 gene and none both of them). Two $(0.8 \%)$ of the Escherichia coli strains studied were eae positive non Shiga toxin-producing. The strains were also examined for resistance to 12 antimicrobial agents. The predominantly observed resistance was to tetracycline $(92.2 \%)$, streptomycin $(90.4 \%)$, nalidixic acid $(88.3 \%)$, amikacin (86.5\%) and cephalothin (84.8\%). Multidrug resistance was found among 152 isolates $(65.8 \%)$.
\end{abstract}

INDEX TERMS: Escherichia coli, mastitis, antimicrobial agents, multidrug resistance, STEC, eae gene.

RESUMO.- [Análise de Escherichia coli isolada de leite de vacas com mastite.] A um longo tempo a mastite tem sido reconhecida como a doença que provoca as maiores perdas econômicas nos rebanhos leiteiros. De fevereiro a novembro de 2004 , foram coletadas 670 amostras de leite mastítico de vacas, provenientes de dois estados brasileiros, das quais foram isoladas 231 cepas de Escherichia coli. Estas cepas foram analisadas para a detecção dos genes de produção de Shiga toxina (stx 1 e stx 2) e do gene da intimina (eae). Vinte cepas $(8,6 \%)$ foram detectadas através de PCR como contendo os genes da Shiga toxina (8stx 1,12 stx 2 e nenhuma delas ambos os genes). Duas cepas $(0,8 \%)$ de $E$. coli eram eae

\footnotetext{
${ }^{1}$ Received on May 18, 2007.

Accepted for publication on December 4, 2008

${ }^{2}$ Programa de Microbiologia, Faculdade de Ciências Agrárias e Veterinárias (FCAV), Universidade Estadual Paulista (Unesp), Campus de Jaboticabal, Via de Acesso Prof. Paulo Donato Castellane $\mathrm{s} / \mathrm{n}$, Jaboticabal, SP 14884-900, Brazil.

${ }^{3}$ Departamento de Morfologia, Estomatologia e Fisiologia (DMEF), Faculdade de Odontologia de Ribeirão Preto (FORP), Universidade de São Paulo (USP), Avenida do Café s/n, Campus USP, Ribeirão Preto, SP 14040-904, Brazil. *Corresponding author: jmmarin@forp.usp.br
}

positivo não produtoras de Shiga toxina. As cepas de $E$. coli foram também examinadas para detectar a resistência a 12 agentes antimicrobianos. As resistências mais freqüentes foram para tetraciclina $(92,2 \%)$, estreptomicina $(90,4 \%)$, ácido nalidixico $(88,3 \%)$, amicacina $(86,5 \%)$ e cefalotina $(84,8 \%)$. A resistência a múltiplas drogas foi encontrada em 152 cepas $(65,8 \%)$.

TERMOS DE INDEXAÇÃO: Escherichia coli, mastite, agentes antimicrobianos, resistência a múltiplas drogas, STEC, gene eae.

\section{INTRODUCTION}

Mastitis remains a major cause of financial loss to the dairy industry and is considered to be economically the most important disease of dairy cattle (Hortet \& Seegers 1998). Classically, mastitis pathogens have been divided into contagious and environmental organisms on the basis of their proclivity to cause persistent or transient opportunistic infections, respectively (Watts 1988).

Dairy cattle with acute mastitis, caused primarily by Escherichia coli, that is classified for this case, as an environmental pathogen, produces a wide range of symptoms, going from a mild disease showing only local 
inflammatory changes of the mammary gland, to a severe form presenting significant systemic signs including rumen stasis, dehydration, shock, and even death (Wenz et al. 2001). The host defense of the bovine mammary gland has been shown to be efficient in controlling and eliminating E. coli infection (Hill et al. 1979); however, this ability has been shown to be less effective during early lactation, due to deficiencies in neutrophil function and number (Shuster et al. 1996).

Numerous studies to identify virulence factors of $E$. coli isolated from cows with clinical mastitis have been conducted (Barrow \& Hill 1989, Kaipainen et al. 2002). Typically, most of the genes found in mastitis strains did not possess any of the virulence genes evaluated (Wenz et al. 2006). The only virulence characteristic consistently associated with $E$. coli isolated from clinical mastitis cows, was serum resistance (Hill 1994).

Shiga toxin-producing E. coli (STEC) strains are considered to be the most important pathogens between a recently emerged group of food borne strains. This type of strain is a major cause of gastroenteritis and also can be responsible for hemorrhagic colitis $(\mathrm{HC})$ or the hemolytic uremic syndrome (HUS), the major cause of acute renal failure in children (Karmali 1989, Paton \& Paton 1998, Beutin et al. 2004). Domestic ruminants, especially cattle, sheep and goats, have suggested to be the principal reservoirs of STEC strains that cause human infections (Zschock et al. 2000, Chapman et al. 2001). Transmission would occurs through consumption of undercooked meat, non-pasteurized dairy products, vegetables and water contaminated by feces containing STEC strains (Paton \& Paton 1998, Caprioli et al. 2005). The STEC strain most frequently associated with clinical disease in the United States and Europe is serotype O157:H7 (Nataro \& Kaper 1998, Caprioli et al. 2005). Nevertheless, since non-O157 STEC strains are the most prevalent ones in animals and as food contaminant, humans are probably more exposed to these strains (Beutin et al. 2004, Blanco et al. 2004). In addition to toxin production, another virulence-associated factor expressed by STEC is a protein called intimin, associated with attaching and effacing lesions and bacterial adherence to epithelial cells; intimin is encoded by the chromosomal gene eae (Nataro \& Kaper 1998).

An acceleration of the emergence of multidrug resistant pathogens has been occurring over the past 10 to 15 years (Shea 2003). Resistance of some bacteria to most of the antimicrobial agents, has become a growing problem in human medicine and in veterinary medicine (Levy 1998). Observations have suggested that the use of antibiotics in animal husbandry is a driving force for the development of antibiotic resistance of certain pathogenic bacterial species (Witte 1998). The use of antibiotics in animal agriculture has been a controversial issue due to the potential transfer of antibiotic resistance from animals to humans. This could have several public health implications that may cause treatment failure, including death and illness prolongation, as well as increasing in the associated costs (Kelly et al. 2004).
The aim of the present study was to determine the virulence genes (stx 1 , st 2 2 and eae) and the susceptibility to 12 antimicrobial drugs of $231 \mathrm{E}$. coli strains isolated from mastitic milk proceedings from two Brazilian states.

\section{MATERIALS AND METHODS}

Bacterial isolates. Milk samples (670) from cows from thirtyseven dairy farms at two Brazilian states (Minas Gerais and Rio Grande do Sul) were aseptically collected between February and November 2004. Teat ends were cleaned using $70.0 \%$ alcohol-moistened swabs and allowed drying. After discarding the first few streams, $2-4 \mathrm{ml}$ of the milk samples was collected into sterile $10 \mathrm{ml}$ glass flasks, and submitted to the California Mastitis Test (CMT) (Schalm \& Noorlander 1957) using a 1-5 scale (Klastrup 1975). CMT-positive samples were refrigerated to about $4^{\circ} \mathrm{C}$ and immediately delivered to the laboratory for analysis. They were plated on MacConkey Agar (Mac-Difco) and incubated for $24 \mathrm{~h}$ at $37^{\circ} \mathrm{C}$. At least five colonies from each plate were selected for analysis. Biochemical confirmation of the strains was performed and E. coli was defined as oxidase negative, indole positive, Simon's citrate negative, urease negative and hydrogen sulfide negative (Koneman et al. 1997).

Determination of stx genes. Bacterial strains (Escherichia coli isolates) grown overnight in nutrient broth (Sigma Chemical Co, St Louis, USA) at $37^{\circ} \mathrm{C}$ were tested for the presence of stx genes (stx 1 and stx 2 ) using the polymerase chain reaction (PCR) protocol of Orden et al. (1998). DNA templates were prepared by pelleting $1 \mathrm{ml}$ of culture enriched by centrifugation at $12000 \mathrm{~g}$. The cell pellet was resuspended into $250 \mu \mathrm{l}$ of sterile distilled water and boiled for $10 \mathrm{~min}$ at $100^{\circ} \mathrm{C}$, again centrifuged and their supernatants subjected to PCR performed in an Eppendorf Mastercycler (Eppendorf AG, Hamburg, Germany). Stx 1 and stx 2 genes were detected using primers and PCR conditions in the above-mentioned protocol. The amplified DNA products were separated by electrophoresis on $1.5 \%$ agarose gel, stained with ethidium bromide and detected under ultraviolet light. Reference E. coli strains used as controls were EDL 933 (O157:H7, stx1, stx 2, eae) and DH5á (negative control).

Characterization of isolates. Isolates were confirmed as $s t x+$ and tested for accessory virulence marker (eae) using the PCR protocol of China et al. (1996).

0157 latex agglutination. The STEC isolates were typed for the O serotype 0157 using the 0157 Latex Agglutination test kit (Oxoid, Basingstoke, Hampshire, UK). The EDL 933 strain was used as a positive control. Negative strains for agglutination were considered non-O157 strains.

Susceptibility testing. Antimicrobial disk susceptibility tests were performed using the disk diffusion method recommended by the National Committee for Clinical Laboratory Standards (NCCLS 1999). Drug-impregnated disks (Cefar, São Paulo, Brazil) were placed onto the surface of the agar using a disk dispenser. The following twelve antimicrobial agents were tested: ampicillin (AMP,10ig); amoxicillin (AMO,10ig), amoxicillin/ clavulanic acid (AMC,30ig); amikacin (AMK,30ig); cephalothin (CFL,30ìg); ceftriaxone (CEF,30ìg); gentamicin (GEN,5ìg); streptomycin (STR,10ìg); nalidixic acid (NAL,30ìg); cotrimoxazole (SUT, 25ìg); ciprofloxacin (CIP,5ìg).

\section{RESULTS}

A total of 231 Escherichia coli strains were isolated from 51 mastitic milk samples positive for Escherichia coli, from 
Table 1. Virulence genes profile of Escherichia coli isolates from mastitic milk obtained from two Brazilian states between February and November, 2004

\begin{tabular}{ccc}
\hline Virulence factor profile & Number of isolates (\%) & STEC \\
\hline stx 1 & $8(3.4)$ & + \\
stx 2 & $12(5.2)$ & + \\
eae & $2(0.8)$ & Non STEC strains
\end{tabular}

Table 2. Antimicrobial susceptibility of 231 Escherichia coli strains isolated from mastitic milk from two Brazilian states from February to November 2004

\begin{tabular}{ccc}
\hline Antimicrobial drugs & $\begin{array}{c}\text { Number of resistant } \\
\text { strains }^{\mathrm{a}}(\%)\end{array}$ & $\begin{array}{c}\text { Number of sensitive } \\
\text { strains }^{*}(\%)\end{array}$ \\
\hline Ampicillin & $137(58.3)$ & $94(40.7)$ \\
Amoxicillin & $133(57.5)$ & $98(42.4)$ \\
Amoxicillin+clavulanic acid & $33(14.3)$ & $198(85.7)$ \\
Cephalothin & $196(84.9)$ & $35(15.1)$ \\
Ceftriaxone & $41(17.7)$ & $190(82.2)$ \\
Tetracycline & $213(92.2)$ & $18(7.8)$ \\
Gentamicin & $157(67.9)$ & $74(32.0)$ \\
Streptomycin & $209(90.5)$ & $22(9.5)$ \\
Amikacin & $200(86.6)$ & $31(13.4)$ \\
Nalidixic acid & $204(88.3)$ & $27(11.7)$ \\
Ciprofloxacin & $120(51.9)$ & $111(48.1)$ \\
Cotrimoxazole & $72(31.1)$ & $159(68.8)$
\end{tabular}

a Intermediate resistant strains were considered as resistant.

a total of 670 mastitc milk samples analyzed. All E. coli isolates were investigated by PCR, for the presence of Shiga-like toxin-producing genes (stx 1 and stx 2 ) and for the intimin (eae) gene. As can be seen from Table 1, 22 $(9.5 \%)$ of the strains harbored the stx and/or the eae genes. PCR showed that $8(3.4 \%)$ of STEC strains carried only the stx 1 gene, $12(5.2 \%)$ the stx 2 gene, and none carried both $s t x 1$ and stx 2 genes; two strains carried only the eae gene. All STEC strains isolated were tested by the 0157 latex agglutination test kit, and no one $\mathrm{O} 157$ isolate was detected.

Among the 231 E. coli isolates tested, the highest resistance was observed against tetracycline (92.2\%), followed by that to streptomycin $(90.4 \%)$ and nalidixic acid (88.3\%); lower resistance to amoxicillin/clavulanic acid and ceftriaxone were detected in $14.2 \%$ and in $17.7 \%$ of the isolates, respectively (Table 2 ). Sixteen isolates were

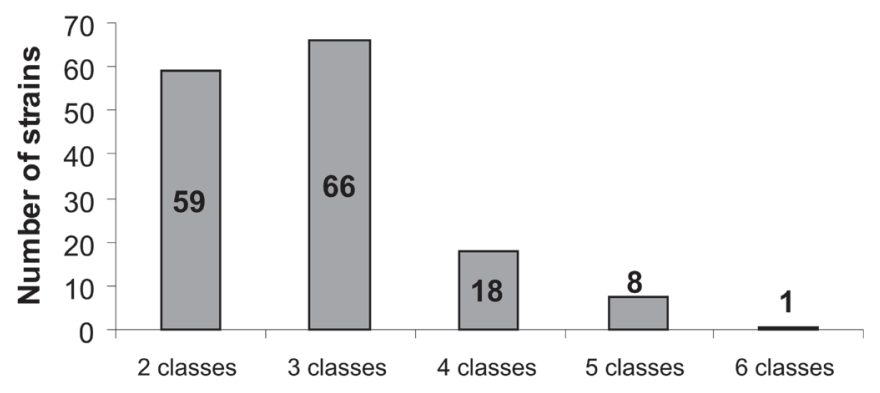

Antimicrobial classes

Fig.1. Distribution of multidrug resistance to 12 antimicrobial drugs among 152 strains of Escherichia coli isolated from bovine mastitic milk.
Table 3. Patterns and phenotypes of antimicrobial drug resistance of 27 strains of Escherichia coli resistant to four or more antimicrobial classes of agents, from mastitic bovine milk

\begin{tabular}{lc}
\hline \multicolumn{1}{c}{ Phenotype } & Number of strains \\
\hline AMP-CFL-TET-STR & 1 \\
AMP-TET-AMK-NAL & 1 \\
CFL-TET-STR-AMK-NAL & 1 \\
AMP-AMC-CFL-TET-AMK & 1 \\
AMP-CFL-TET-GEN-STR & 1 \\
AMP-TET-GEN-AMK-NAL & 1 \\
AMP-CFL-GEN-STR-AMK-CIP & 1 \\
SUT-TET-GEN-STR-AMK-NAL & 1 \\
AMP-CFL-GEN-AMK-NAL-CIP & 1 \\
AMP-AMO-CIP-GEN-AMK-NAL & 1 \\
AMP-TET-STR-AMK-NAL-CIP & 1 \\
AMO-TET-GEN-STR-AMK-CIP & 1 \\
AMP-CFL-TET-GEN-STR-AMK & 1 \\
AMO-TET-GEN-STR-AMK-NAL & 1 \\
AMO-TET-GEN-STR-AMK-CIP & 1 \\
AMC-CFL-TET-GEN-AMK-NAL & 1 \\
AMC-CFL-TET-GEN-STR-AMK-NAL & 1 \\
TET-GEN-STR-AMK-NAL-CIP-SUT & 1 \\
AMP-AMO-TET-GEN-STR-AMK-SUT & 1 \\
AMP-AMO-CFL-GEN-STR-AMK-SUT & 1 \\
AMP-AMO-CFL-TET-STR-AMK-SUT & 1 \\
AMP-AMO-CFL-TET-STR-AMK-CIP & 1 \\
AMO-AMC-CFL-TET-GEN-AMK-NAL & 1 \\
AMP-TET-GEN-STR-AMK-NAL-CIP-SUT & 1 \\
AMP-AMO-AMC-CFL-TET-STR-AMK-NAL & 1 \\
AMP-AMO-CFL-TET-GEN-STR-AMK-CIP & 1
\end{tabular}

susceptible to all antimicrobial agents tested, and 152 isolates were resistant to two or more antimicrobial classes (Fig.1). The multidrug resistant phenotypes (resistance to more than 4 antimicrobial classes) for the 27 isolates of E. coli, are depicted on Table 3.

\section{DISCUSSION}

Mastitis has been recognized for some time as the most costly disease in dairy herds (Miller et al. 1993). Based on epidemiological studies, it has been hypothesized that cows are infected with Escherichia coli from their environment, as feces and straw (Lipman et al. 1995). It is well known that bacterial, hosts and environmental factors are interdependent and influence susceptibility to mastitis. Many studies performed during the last decade indicate that the severity of $E$. coli mastitis is mainly determined by host's factors, rather than by $E$. coli pathogenicity (Burvenich et al. 2003). Dogan et al. (2006) examined $E$. coli strains associated with intramammary infection and demonstrated the absence in them of either K99, F1845, LT, Sta, Stb, stx 1, stx 2, cnf 1, cnf 2, eae, pap, sfa, afa, hly and ipa $\mathrm{H}$ or other known genes associated with virulence and invasion.

Out of $279 \mathrm{E}$. coli isolates investigated by Linton \& Howe (1979), 217 (77.1\%) could be O-serogrouped, and 67 different $\mathrm{O}$-serogroups were found. This indicates that $E$. coli mastitis is not caused by a limited number of specific pathogenic strains, but seems to be associated with environmental fecal contamination and be multifactorial. 
Cattle have long been regarded as the principal reservoir of STEC strains including those belonging to serotype O157:H7 (Paton \& Paton 1998). More than 200 different STEC serotypes have been isolated from cattle, some being more frequently isolated than others (Beutin et al. 2004, Caprioli et al. 2005). In Brazil, only a few studies have reported the isolation and the characteristics of STEC in cattle (Cerqueira et al. 1999, Leomil et al. 2003, Salvadori et al. 2003, Irino et al. 2005); all of them were from healthy or cattle presenting diarrhoea. Only Lira et al. (2004) have reported the isolation of STEC strains from mastitic milk, the carriage of stx gene (12.08\%) and the distribution of $22.7 \%$ (stx 1$)$ and $45.5 \%$ (stx 2$)$ genes. This agrees with the results reported in the present study: stx carriage (8.6 $\%$ ), was distributed between $40.0 \%$ (stx 1 ), and $60.0 \%$ (stx 2), with a predominance of stx 2 gene in both studies, in agreement with the results of Hornitzky et al. (2002) in Australia, Zschok et al. (2000), in Germany, and Irino et al. (2005), in Brazil.

Another objective of this study was to characterize STEC from dairy cows for their virulence markers and for possible relationships with known human pathogenic types of Escherichia coli. The eae gene is responsible for attachment and effacement lesions similar to those observed in enteropathogenic E. coli (Gannon et al. 1993). Eae genes are present in most human STEC strains belonging to enterohaemorrhagic serotypes. In the present study, the eae gene was not detected in the STEC isolates herein studied. The low prevalence of eae-positive STEC strains has been reported in several studies (Beutin et al. 1993, Zschok et al. 2000, Irino et al. 2005). However, in this study a small percentage of E. coli strain $(0.8 \%)$ (results not shown) were eae positive but none harbored stx genes. Other authors also detected eae-positive nonSTEC strains (Mainil et al. 1993, Orden et al. 1998, Kobori et al. 2004). The pathogenicity of eae-positive non-STEC in calves is not clear, but Fischer et al. (1994) showed that an eae-positive verotoxigenic-negative strain was able to experimentally induce the attaching and effacing lesion. As suggested by Wieler et al. (1996) the eae-positive $E$. coli strains isolated from cattle may harbor genes that are structurally different from, but functionally identical, to the EPEC genes.

Prevalence and extent of antimicrobial resistance in a population is strongly correlated to antibiotic usage, since selection and dissemination of resistant bacteria are greatly increased by the pressure exerted by these drugs. As a consequence, resistance is most commonly found where there occurs heavy use of antibiotics and appreciable host to host contact; therefore, sites of intensive farming constitute a large reservoir of antibiotic- resistant bacteria (Murray 1992). In this situation, resistant microorganisms are very easily disseminated within units via fecal contact, promoting contamination of the water used by animals or environmental contamination of the soil (Teuber 2001). Among the 231 isolates tested in this work, E. coli antimicrobial drug susceptibilities were high especially for amoxicillin+ clavulanic acid (85.7\%), ceftriaxone (82.2\%) and cotrimoxazole (68.8\%) (Table 2).

Zhao et al. (2001) examined 50 strains of E. coli Shiga toxin-producing (STEC), 290157 strains and 21 non-O157 strains; both groups showed high resistance level to ampicillin, tetracycline and streptomycin, in agreement with the present study (Table 2). The authors reported that $78.0 \%$ of the strains exhibited resistance to two or more antimicrobial agents; among them the resistant phenotype for streptomycin, tetracycline and sulfametoxazole was the most commonly observed. In the present study a high multidrug resistance (65.8\%) was reported (Fig.1).

In Europe there exist two different situations related to antimicrobial utilization; some countries like Spain do not exert a rigid control over antimicrobial agents utilization, while other ones like Sweden and Denmark exerted such control. Orden et al. (2000) examined 195 E. coli strains isolated from diarrheic cattle in Spain and reported a high resistance to ampicillin, tetracycline, streptomycin and trimethropim, agreeing with the results presented in this work (Table 2); the authors also reported a great number of multiresistant strains $(76.9 \%), 67.7 \%$ of them resistant to four or more drugs. When Lanz et al. (2003) in Sweden, examined the susceptibility of $581 \mathrm{E}$. coli strains to 16 antimicrobial drugs, they reported a discrete level of resistance to ampicillin $(21.0 \%)$ followed by streptomycin $(22.0 \%)$ and tetracycline $(20.0 \%)$ and total susceptibility to the other antimicrobial drugs tested in $80.0 \%$ of the bacterial strains examined.

In Brazil, Langoni et al. (2000) reported a discrete level of resistance to tetracycline (13.0\%) and ampicillin (12.0\%) among $E$. coli isolates from bovine mastitis, while Amaral et al. (1996) also reported high levels of resistance to ampicillin $(92.9 \%)$ and tetracycline $(71.4 \%)$ of bovine mastitis isolates. The data reported in the present study agree with those reported by Baptista \& Marin (2006) for isolates from mastitic and diarrheic cattle, showing an intermediate level between those reported above.

Although antibiotic resistance patterns may reflect the antibiotics used for mastitis prevention and treatment, some authors (Hillerton \& Berry 2005) defended the idea that convincing evidence is still lacking for supporting this theory. Studies performed in the United States indicate that there is no correlation among increased resistance of and antimicrobials that are commonly used in dairy cattle for treatment of mastitis (Erskine et al. 2001, Makovec \& Ruegg 2003). In Switzerland, there was no increased antibiotic resistance of mastitis pathogens during the last 20 years (Roesch et al. 2006), indicating different points of view about this theme. In Brazil a strong control of antimicrobial drugs commercialization and access to data related to resistance to antimicrobial drugs presented by the pathogens responsible for bovine mastitis would first be necessary before a conclusive answer about this matter is given.

Concluding, the present study demonstrated the presence, in a low number, of STEC strains among those 
isolated from bovine's mastitis cases. Also it was observed a high level of antimicrobial resistance to many antibiotics and an elevated number of multiresistant strains among the E. coli strains examined.

Acknowledgements.- The authors thank Dr. Maria da Graça Portantiolo Correa, Vitafort Co Ltd, for milk samples. This paper is part of a thesis submitted by Patricia Rangel to the Faculdade de Ciências Agrárias e Veterinárias, Unesp-Jaboticabal, in fulfillment of the requirements for the Master's degree.

\section{REFERENCES}

Amaral L.A., Nader-Filho A., Rossi Junior O.D. \& Penha L.C.A. 1996. Ação de antibióticos e quimioterápicos sobre alguns agentes bacterianos da mastite bovina, isolados da água utilizada no processo de obtenção do leite. Arq. Bras. Med. Vet. Zootec. 48:525-32.

Baptista A. \& Marin J.M. 2006. In vitro susceptibility to 11 antimicrobial agents of Escherichia coli isolated from diarrheic and mastitic cattle in São Paulo State, Brazil. Ars Vet., Jaboticabal, 22:31-36.

Barrow P.A. \& Hill A.W. 1989. The virulence characteristics of strains of Escherichia coli isolated from cases of bovine mastitis in England and Wales. Vet. Microbiol. 20:35-48.

Beutin L., Geier D., Steinruch H., Zimmermann S. \& Scheutz F. 1993. Prevalence and some properties of verotoxin (Shiga-like-toxin)producing $E$. coli in seven different species of healthy domestic animals. J. Clin. Microbiol. 31:2483-2488.

Beutin L., Krause G., Zimmermann S., Kaulfuss S. \& Gleier K. 2004. Characterization of Shiga toxin-producing Escherichia coli strains isolated from human patients in Germany over a 3-year period. J. Clin. Microbiol. 42:1099-1108.

Blanco M., Blanco J.E., Mora G., Dahbi G., Alonso M.P., Gonzalez E.A., Bernardez M.I. \& Blanco J. 2004. Serotypes, virulence genes, and intimin types of Shiga toxin (verotoxin)-producing Escherichia coli isolates from cattle in Spain and identification of a new intimin variant gene (eae $)$ ). J. Clin. Microbiol. 42:645-651.

Burvenich C., Van Merris V., Mehrzad J., Diez-Fraile A. \& Duchateau L. 2003. Severity of $E$. coli mastitis is mainly determined by cow factors. Vet. Res. 34:521-564.

Caprioli A., Morabito S., Brugere H. \& Oswald E. 2005. Enterohaemorrhagic Escherichia coli: emerging issues on virulence and modes of transmission. Vet. Res. 36:289-311.

Cerqueira A.M.F., Guth B.E.C., Joaquim R.M. \& Andrade J.R.C. 1999. High occurrence of Shiga toxin-producing Escherichia coli (STEC) in healthy cattle in Rio de Janeiro State, Brazil. Vet. Microbiol. 70:111121.

Chapman P.A., Cerdan-Malo T., Ellin M., Ashton R. \& Harkin M.A. 2001. Escherichia coli 0157 in cattle and sheep at slaughter, on beef and lamb carcasses, and in raw beef and lamb products in South Yorkshire, UK. Int. J. Food. Microbiol. 64:139-150.

China B., Pirson V. \& Mainil J. 1996. Typing of bovine attaching and effacing Escherichia coli by multiplex in vitro amplification of virulenceassociated genes. Appl. Environ. Microbiol. 62:3462-3465.

Dogan B., Klaessig S., Rishniw M., Almeida R.A., Oliver S.P., Simpson K. \& Schukken Y.H. 2006. Adherent and invasive Escherichia coli are associated with persistent bovine mastitis. Vet. Microbiol. 116:270282.

Erskine R.J., Walker R.D., Bolin C.A., Barlett P.C. \& White D.G. 2001. Trends in antibacterial susceptibility of mastitis pathogens during a seven-year period. J. Dairy Sci. 85:1111-1118.

Fischer J., Maddox C., Maxley R., Kinden D. \& Miller M. 1994. Pathogenicity of a bovine attaching effacing $E$. coli isolate lacking Shiga-like toxins. Am. J. Vet. Res. 55: 991-999.

Gannon V.P.J., Rashed M., King R.K. \& Golsteyn T.E.J. 1993. Detection and characterization of eae gene of Shiga-like toxin-producing $E$. coli using polymerase chain reaction. J. Clin. Microbiol. 31:1268-1274.

Hill A.W. 1994. Escherichia coli mastitis, p.117-133. In: Gyles C.L. (Ed.), Escherichia coli in Domestic Animals and Humans. CAB International, Wallingford, UK.

Hill A.W., Shears A.L. \& Hibbit K.G. 1979. The survival of serum resistant Escherichia coli in the bovine mammary gland following experimental infection. Res. Vet. Sci. 26:32-37.

Hillerton J.E. \& Berry E.A. 2005. Treating mastitis in the cow-a tradition or an archaism. J. Appl. Microbiol. 98:1250-1255.

Hornitzky M.A., Vanselow B.A., Walker K., Bettelheim K.A., Corney B., Gill P., Bailey G. \& Djordjevic S.P. 2002. Virulence properties and serotypes of Shiga toxin-producing Escherichia coli from healthy Australian cattle. Appl. Environ. Microbiol. 68:6439-6445.

Hortet P. \& Seegers H. 1998. Loss in milk yield and related composition changes resulting from clinical mastitis in dairy cows. Rev. Prev. Vet. Med. 37:1-20.

Irino K., Kato M.A.M.F., Vaz T.M.I., Ramos I.I., Souza M.A.C., Cruz A.S., Gomes T.A.T., Vieira M.A.M. \& Guth B.E.C. 2005. Serotypes and virulence markers of Shiga toxin-producing Escherichia coli (STEC) isolated from dairy cattle in São Paulo State, Brazil. Vet. Microbiol. 105:29-36.

Kaipainen T., Pojanvirta T., Shpigel N.Y., Shwimmer A., Pyorala S. \& Pelkonen S. 2002. Virulence factors of Escherichia coli isolated from bovine clinical mastitis. Vet. Microbiol. 85:37- 46.

Karmali M.A. 1989. Infection by verocytotoxin-producing Escherichia coli .Clin. Microbiol. Rev. 2:15-38.

Kelly L., Smith D.L., Snary E.L., Johnson J.A., Harris A.D., Wooldrige M. \& Morris Jr J.G. 2004. Animal growth promoters: To ban or not to ban? A risk assessment approach. Int. J. Antimicrob. Agents 24:205212.

Klastrup N.O. 1975. Scandinavian recommendation on examination of quarter milk samples. Int. Dairy Fed. Ann. Bull. 85:49-52.

Kobori D., Rigobelo E.C., Macedo C., Marin J.M. \& Ávila F.A. 2004. Virulence properties of Shiga toxin-producing Escherichia coli isolated from cases of bovine mastitis in Brazil. Revue Elév. Méd. Vét. Pays Trop. 57:15-20.

Koneman E.W., Allen S.D., Schrekenberger P., Janda C. \& Winnl W.C. 1997. Color Atlas and Textbook of Diagnostic Microbiology. 5th ed. Lippincott Company, Philadelphia.

Langoni H., Araújo W.N., Silva A.V. \& Souza L.C. 2000. Tratamento da mastite bovina com amoxicilina e enrofloxacina bem como a sua associação. Arq. Inst. Biológico, São Paulo, 67:177-180.

Lanz R., Kuhnert P. \& Boerlin P. 2003. Antimicrobial resistance and resistance gene determination in clinical Escherichia coli from different animal species in Switzerland. Vet. Microbiol. 91:73-84.

Leomil L., Aidar-Ugrinovich L., Guth B.E.C., Irino K., Vettorato M.P., Onuma D.L. \& Castro A.F.P. 2003. Frequency of Shiga toxin-producing Escherichia coli (STEC) isolates among diarrheic and non-diarrheic calves in Brazil. Vet. Microbiol. 97:103-109.

Levy S.B. 1998. The challenge of antibiotic resistance. Scient. American 278:46-53.

Linton A.H. \& Howe K.A. 1979. A note on the range of Escherichia coli O-serotypes causing clinical bovine mastitis and their antibiotic resistance spectra. J. Appl. Bacteriol. 46:585-590.

Lipman L.J.A., de Nijs A., Lam T.J.G.M. \& Gaastra W. 1995. Identification of Escherichia colistrains from cows with clinical mastitis by serotyping and DNA polymorphism patterns with REP and ERIC primers. Vet. Microbiol. 43:13-19.

Lira W.M., Macedo C. \& Marin J.M. 2004. The incidence of Shiga toxinproducing Escherichia coli in cattle with mastitis in Brazil. J. Appl. Microbiol. 97:861-866.

Mainil J.G., Jacquemin E., Kaeckenbeeck A. \& Pohl P. 1993. Association 
between the effacing gene (eae) and the Shiga-like toxin-encoding genes in Escherichia coli isolates from cattle. Am. J. Vet. Res. 54:1064-1068.

Makovec J.A. \& Ruegg P. 2003. Antimicrobial resistance of bacteria isolated from dairy cow milk samples submitted for bacterial culture: 8905 samples (1994-2001). J. Am. Vet. Med. Assoc. 222:1582-1589.

Miller G.Y., Barlett P.C., Lance S.E., Anderson J. \& Heider L.E. 1993. Costs of clinical mastitis and mastitis prevention in dairy herds. J. Am. Vet. Med. Assoc. 202:1230-1236.

Murray B.E. 1992. Problems and dilemmas of antimicrobial resistance. Pharmacotherapy 12:S86-S93.

Nataro J.P. \& Kaper J.B. 1998. Diarrheagenic Escherichia coli. Clin. Microbiol. Rev. 11:142-201.

National Committee for Clinical Laboratory 1999. Performance standards for antimicrobial disk dilution susceptibility test for bacteria isolated from animals approved Standard M31A, vol.19, no.11. National Committee for Clinical Laboratory Standards, Wayne, PA.

Orden J.A., Ruiz-Santa-Quiteria J.A., Cid D., Garcia S., Sanz R. \& de La Fuente R. 1998. Verotoxin-producing Escherichia coli (VTEC) and eae-positive non-VTEC in 1-30 days-old diarrhoeic dairy calves. Vet. Microbiol. 63:239-248.

Orden J.A., Ruiz-Santa-Quiteria J.A., Garcia S., Cid D. \& de La Fuente R. 2000. In vitro susceptibility of Escherichia coli strains isolated from diarrhoeic dairy calves to 15 antimicrobial agents. J. Vet. Med. Bull. 47:329-335.

Paton J.C. \& Paton A.W. 1998. Pathogenesis and diagnosis of Shiga toxin-producing Escherichia coli infection. Clin. Microbiol. Rev. 11:450479.

Roesch M., Perreten V., Doherr M.G., Schaeren W., Schallibaum M. \& Blum J.W. 2006. Comparison of antibiotic resistance of udder pathogens in dairy cows kept on organic and on conventional farms. J. Dairy Sci. 89:989-997.

Salvadori M.R., Valadares G.F., Leite D.S., Blanco J. \& Yano T. 2003. Virulence factors of Escherichia coli isolated from calves with diarrhea in Brazil. Braz. J. Microbiol. 34:230-235.

Schalm D.W. \& Noorlander D.O. 1957. Experiments and observation leading to development of the California Mastitis Test. J. Am. Vet. Med. Assoc. 130:199-204.

Shea K.M. 2003. Antibiotic resistance: What is the impact of agricultural uses of antibiotics on children health? Pediatrics 112:253-258.

Shuster D.E., Lee E.K. \& Kehrli Jr M.E. 1996. Bacterial growth, inflammatory cytokine production, and neutrophil recruitment during coliform mastitis in cows within ten days after calving, compared with cows at midlactation. Am. J. Vet. Res. 57:1569-1575.

Teuber M. 2001. Veterinary use and antibiotic resistance. Curr. Opin. Microbiol. 4:493-499.

Watts J.L. 1988. Etiological agents of bovine mastitis. Vet. Microbiol. 16:41-66.

Wenz J.R., Barrington G.M., Garry F.B., Dinamore R.P. \& Callan R.J. 2001. Use of systemic disease signs to assess disease severity in dairy cows with acute coliform mastitis. J. Am. Vet. Med. Assoc. 218:567-572.

Wenz J.R., Barrington G.M., Garry F.B., Ellis R.P. \& Magnuson R.J. 2006. Escherichia coli isolates serotypes, genotypes, and virulence genes and clinical coliform mastitis severity. J. Dairy Sci. 89:34083412.

Wieler L.H., Vieler E., Erpenstein C., Schlapp T., Steinruck H., Bauerfeind R., Byomi A. \& Baljer G. 1996. Shiga toxin producing Escherichia coli strains from bovines association of adhesion with carriage of eae and other genes. J. Clin. Microbiol. 34:2980-2984.

Witte W. 1998 Medical consequences of antibiotic use in agriculture. Science 279:996-997.

Zhao S., White D.G., McDermott P.F., Friedman S., English L., Ayers S., Meng J., Maurer J.J., Holand R. \& Walker R.D. 2001. Identification and expression of cephamycinase bla CMY genes in Escherichia coli and Salmonella isolates from food animals and ground meat. Antimicrob. Agents Chemoth. 45:3647-3650.

Zschock M., Hamann H.P., Kloppert B. \& Wolter W. 2000. Shiga-toxinproducing Escherichia coli in faeces of healthy dairy cows, sheep and goats: prevalence and virulence properties. Lett. Appl. Microbiol 31:203-208. 